\title{
Optimising the amount of base material used for manufacturing garments with creases, during their design stage \\ DOI: 10.35530/IT.072.04.1845
}

MANUELA AVĂDANEI

ANTONELA CURTEZA

CARMEN BLEJAN

IONUT, DULGHERIU
EMIL CONSTANTIN LOGHIN

DORIN IONESI

CEZAR-DORU RADU

\section{ABSTRACT - REZUMAT \\ Optimising the amount of base material used for manufacturing garments with creases, during their design stage}

The clothing and fashion industry is known as a wasteful industry. Despite its target, producing fashionable and beautiful items to fulfil the needs of different consumer categories consumes a considerable quantity of raw materials, energy, water, labour force, etc. Every year, natural resources become more limited, hard to find and expensive; in these terms, the producers are forced to find either alternative solutions to replace as much as they can the needed primary raw materials or to try to maximise their use (which means to reduce the quantity of waste) or to use the waste to produce other things. The consumption of raw materials is determined during the development stage of the new model: the designer analyses the sketch of the selected model, then establishes and applies the needed steps to design the model pieces, creates the $3 D$ virtual or supervises the manufacturing process of the physical prototype to verify the design solution, applies changes after analysing the prototype if it is necessary, obtains the production patterns and then he/she is doing the markers to determine the consumption of raw materials for one item and the whole order. Garment models with creases, pleats or folds are the most challenging ones because the designer has to have the ability to understand and to evaluate the shadows or the number of grouped lines of the model into values of distances or angles, to be used to change the element surface for their realisation. In these cases, it is essential to balance what the model requires and the needed amount of raw materials to produce it. This paper proposes some variants of how to resize the surfaces of the elements for designing creases but with an optimal raw material consumption level. The results are based on the analysis of different men jacket models', with straight silhouette and creases between the hemline and its hem band.

Keywords: optimised consumption, element surface, depth creases, pattern modelling

\section{Optimizarea consumului specific de material de bază pentru modele de produse de îmbrăcăminte} ce prezintă cute, din etapa de proiectare conceptuală a acestora

Industria de îmbrăcăminte și de modă este cunoscută ca o industrie în care se produc multe deșeuri. În ciuda obiectivului său, de a produce articole frumoase și în tendințe pentru a satisface nevoile diferitelor categorii de consumatori, în confecționarea produselor se consumă o cantitate considerabilă de materii prime, energie, apă, forță de muncă etc. În fiecare an, resursele naturale devin mai limitate, greu de găsit și costisitoare; în aceste condiții, producătorii sunt obligați să identifice soluții alternative de surse primare de materii prime necesare confecționării noilor modele, sau să maximizeze modul de utilizare al suprafeți acestora (implicit cu reducerea cantității de deșeuri) sau să folosească deșeurile pentru a fabrica alte produse. Consumul de materii prime este determinat în etapa de dezvoltare a noului model: proiectantul analizează schița modelului selectat, apoi stabilește și aplică pașii necesari pentru proiectarea pieselor modelului, creează prototipul virtual 3D sau supraveghează procesul de fabricație al prototipului fizic pentru verificarea/validarea soluției de proiectare, aplică modificările necesare, dacă prototipul nu îndeplinește condițiile impuse, obține tiparele de producție și apoi realizează încadrări pentru determinarea consumul de materii prime pe produs și total comandă. Modelele produselor de îmbrăcăminte cu pliuri, cute sau creți sunt modele care ridică mari probleme, deoarece proiectantul trebuie să aibă capacitatea de a înțelege și de a evalua umbrele sau numărul de linii grupate ale modelului în valori care să exprime distanțe sau unghiuri, pe care le utilizează în prelucrarea suprafeței reperului de produs în care apar acestea. În aceste cazuri, este important să se găsească un echilibru între modul de transformare a suprafeței elementului de produs pentru obținerea creților și consumul de materii prime necesar fabricației acestuia. Această lucrare propune câteva variante de prelucrare a suprafețelor elementelor de produs pentru proiectarea cutelor, dar cu optimizarea nivelului de consum al materialului de bază, necesar fabricației acestuia. Studiul are la bază modele de jachete pentru bărbați, care au cute pe linia de montare a beteliei.

Cuvinte-cheie: consum optimizat, suprafața elementului, adâncimea cutei, modelare tipar

\section{INTRODUCTION}

The ongoing pandemic has influenced all aspects of our lifestyle due to the quarantines, restrictions upon travel and professional activities, school closures, supply chain disruptions, online work, and shopping, etc. Our daily lives have been dramatically changed, and we have arrived at a point when society has to adapt to this situation in all aspects: personal, social, professional, economic, etc. [1]. 
The manufacturers have had to change their business approach by focusing on producing items ondemand at optimised costs and becoming better at predicting future demands. This situation is quite tricky because it requires predicting the customers' needs, targeting sales, and estimating the number of items that have to be manufactured in the future. To be competitive, manufacturers must digitalise their production process by using IT solutions and ensure that they have highly skilled employees who can exploit this virtual reality to the best possible extent by being creative, innovative, and original in their work. In a digitalised world, some manufacturing tasks are automated; machine sensors are used increasingly often, the customers can communicate with the manufacturers and get updates regarding their orders. Producers can keep their business efficient and in line with the customers' demands by employing predictive analysis (by forecasting future or otherwise strange events), robotics (by using artificial intelligence and customisable technologies in order to meet business and customer demands), machine learning(in order to identify and anticipate the factors that impact daily operations, such as the speed and the quality of the assembly lines), enterprise resource planning (by automating different types of manufacturing operations under a straightforward system), B2B eCommerce i.e., business-tobusiness electronic commerce(in order to boost sales), cloud-driven network solutions(by employing flexible IT network platforms in order to adapt to the rapidly changing nature of business and customers' demands) [2-4].

Digitalisation provides the opportunity to explore diversified solutions for one problem to select the best one while adding value to the produced items without creating waste, carbon footprint, etc. In a virtual environment, designers are provided with the proper tools, functions, and instruments for developing personalised models by integrating the customer's data and preferences: the body measurements (either scanned or specified by the customer), the dimensions of the model, and types of material and accessories (co-design process). One can also check the designed model's dimensions to determine whether it meets the technical specifications or estimates the manufacturing cost for a component [5].

The following factors influence the amount of raw material that is required in the production process: the type of the model, the size, structure and purpose, fashion lines and restrictions (volume, number of pieces, shape), manufacturing process, physical properties of the materials, and the geometry of the outline contour lines of the garment pieces. For a designer, the most challenging part in the development process of a model is to estimate its volume in order to be able to create the required creases, folds, or pleats. The sketch of the model also includes some shadows or group of lines, and these signs have to be interpreted in terms of distances or angles. Using their technical experience and knowledge, a designer might estimate these distances' values, but the latter can be validated after the model has been manufactured (model prototype). The virtual prototype of the designed model is obtained with 3D modules of CAD's software. The prototype fitting degree is analysed when dressed on the adequate virtual mannequin (client avatar) by considering the materials' properties in its structure and types of seams. The designer analysis the volume of the model or the level and the shape of the necessary cutting lines, evaluates its balance on the virtual avatar, and decides if something has to be changed (validating the adopted design solution). Afterwards, they realise markers to determine the necessary quantities of raw materials and estimate the model's price. The person in charge of elaborating the model's technical documentation decides if the model has been welldesigned; if the model meets the customer's requirements, it will continue its "journey" to the production lines.

In the markers, the designer analysis the geometry and shape of the element, the one designed for creases, because its bigger surface influences the model consumption. Based on his/her technical experience, he/she decides if there are any possibilities to improve the material usage by optimising the piece surface in its design phase. If something is changed in the $2 \mathrm{D}$ shape of the piece, then it is necessary to generate the $3 \mathrm{D}$ virtual prototype, put it on the avatar and see if the new shape of the pieces (or pieces) conduct to the desired model $[6,7]$.

The produced garment model has to fulfil the customer's needs: it has to be of good quality, fashionable, well-fitted, comfortable, and affordable. The comfort is influenced by its size, silhouette, volume, and types of materials used in the manufacturing process. Any garment exerts pressure on its support area because it depends on its volume and structure. If the garment has pleats, creases, or folds, it must also contain oversized elements in its structure to facilitate its realisation, which means that it will be heavier and require larger quantities of material. The designer must balance the garment volume and the necessary amount of material to produce a sustainable item for the client while following all the model specifications [8].

This paper presents the results of a study involving a garment model with creases, whose aim is to illustrate how one can resize the surface of its components to obtain these pieces while also optimising the amount of material used in the manufacturing process. The study has been carried out on a jacket model for men, with creases between the hemline and its hem band.

\section{RESEARCH DEVELOPMENT STAGES}

The research has been carried out in two main stages:

- Designing the patterns of the established models.

- Determining the necessary amount of base material and analysing the results to decide which option is best suited for manufacturing sustainable products 
and optimising the amount of material used in the production process.

\section{Designing the garment model patterns}

The designer must construct the model's patterns and determine the necessary amount of base material for multiple design options. By analysing the results, the designer decides the best way the patterns have to be changed to optimise the necessary amount of material (base material). The model patterns are designed in a customised manner (by using the functions provided by the Gemini CAD Made-to Measure module) because their shape and size will automatically change when the data used in the design algorithm is altered [9-12].

Figure 1 presents the basic model for a men's jacket, which is used for developing different models with creases on the hemline. The patterns of the selected model are designed using the geometric method.

Model details: The jacket is of medium length, has a straight silhouette and a knitted hem band. Knitted material is also used for the collar and for the sleeve cuffs too. The width of the latter is about $7 \mathrm{~cm}$, and their length is standard. The front and the back parts of the jacket have individual yokes. The jacket has a long zipper placed on the front middle line. The back side consists of two pieces- the yoke and the main element, while the front side is made of two piecesthe yoke and the front. The jacket's structure consists of the following layers of materials: base, lining, and interlining.

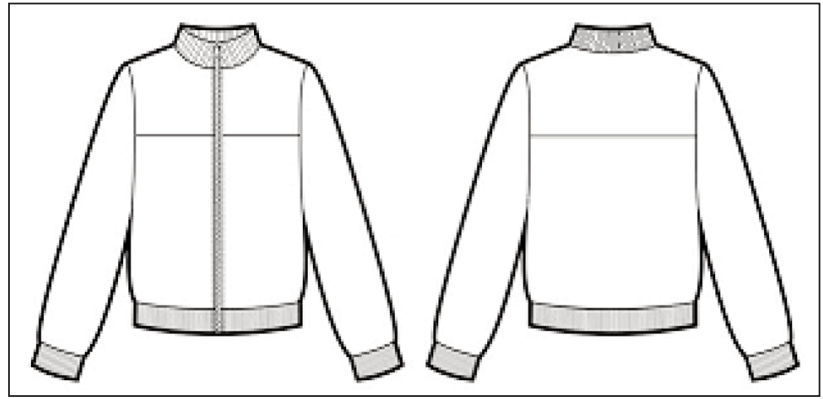

Fig. 1. The basic model of the men jacket

The men jacket patterns are designed using mathematical relations. The design solution is choused by considering the garment type, customer gender and age, and model silhouette. The main points of the patterns are positioned in the geometric layer by the written mathematics relations. The points are connected with lines (straight or curves) to obtain the element shape.

The garment model pieces are designed in the geometric layer, too. In this way, the user controls the established values of the needed modifications related to the model features and customer size. The sleeve patterns are drafted following the front and back elements to obtain the armhole's desired shapes and the sleeve heads (figure 2).

Figure 3 shows the models used to reach the paper goal. These models have creases with different

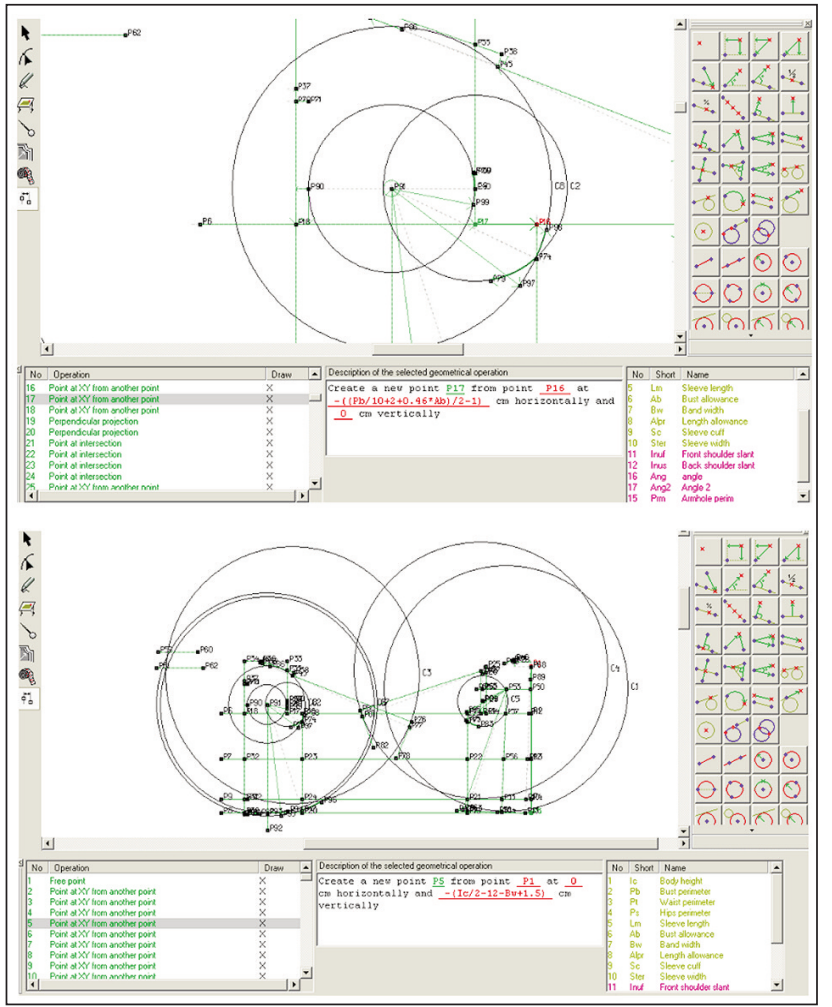

Fig. 2. Design scenario within the Made-to-Measure module (GeminiCAD)

depths, uniformly distributed on the front and back sewing lines with the hem band.

The shape of the pieces with different depths is obtained by applying the isometric principle of altering the components' surface: front and back (figure 3). By the sketch of the model, the surface of the front and back elements is altered by using different combinations of values from $4 \mathrm{~cm}$ to $20 \mathrm{~cm}$ (the designer analyses the sketch and selects the values according to the number of lines that are grouped in the same place). The distances mentioned above are computed as angles and declared as initial data, and used to change the piece surface for obtaining creases. These values are customised by taking the garment size into account [9-13].

The basic shape of the front and the back pieces (designed in MTM scenario, as it is sown in figure 2) are changed with different angles (figure 4) to obtain the models from figure 3 . After that, the model patterns are transformed into production patterns and used to do the markers.

\section{Determining the necessary amount of base material}

To realise the markers, one considers the following: the same value for the width of the base material, the same number of sizes, the material has no restriction regarding the orientation of the pieces on warp direction. There were choused and analysed 61 possibilities of models with different values of crease depths; the creases were uniformly distributed on the hemline in the front and back main pieces (figure 5). The values of the needed depths were from $4 \mathrm{~cm}$ to 

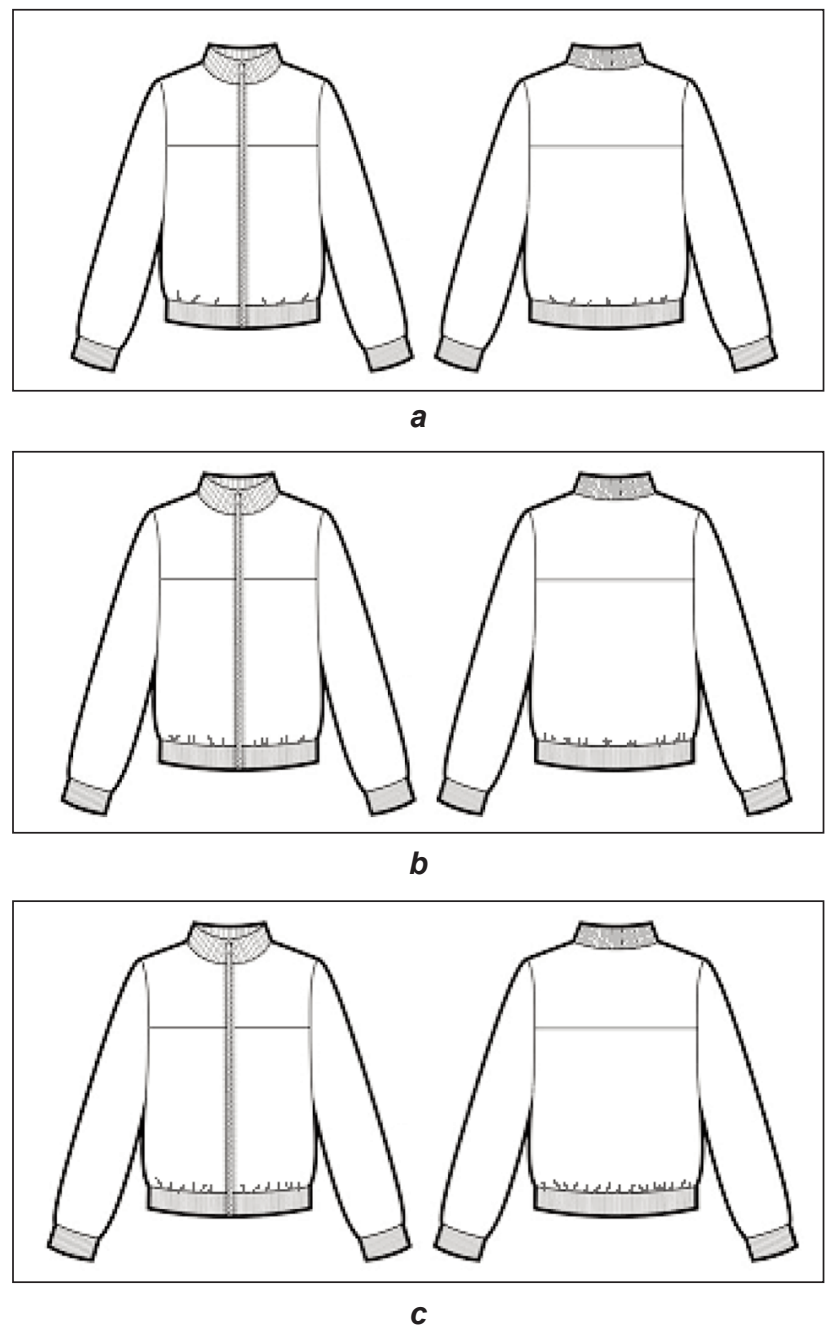

Fig. 3. Men jacket models: a - small number of creases, with a small depth, uniformly distributed on the front and back; $b$ - medium number of creases, with a small or medium depth, uniformly distributed on the front and back; $c$ - significant number of creases, with a small or medium depth, uniformly distributed on the front and back
$20 \mathrm{~cm}$. It was avoided using the maximal value for the smallest size of the model or the minimal value for its biggest size [10].

The marker length is influenced by the number of sizes placed in the marker, the width of the material, the number of pieces that comprise the garment model, and the components' geometry; it strictly determines the usage index of the material. If in a marker are placed small pieces that belong to a different model, the value of the usage index is improved (the waste index is small).

The results obtained after doing all the markers were analysed using the TC3D program [14]. The influence of increasing the areas of the front and the back pieces on the material surface usage index was studied as well. The program generates a list of different mathematical models which represent the correlation between the selected variables: $X \rightarrow$ the percentage increase of the back; $Y \rightarrow$ the percentage increase of the front; $Z \rightarrow$ the usage index of the material surface. The mathematical model that expresses the relation between the aforementioned parameters was selected by taking into account some criteria: Fstatistic > Fstd error. The model coefficients' values had to be significant from a statistical point of view (95\% confidence level). In the end, we selected the model from the generated list, which best fits the experimental data (figure 6).

\section{CONCLUSIONS}

The person who designs the patterns for the garment models with a reduced number of pieces and with creases must be proficient in patterning, understanding and interpreting all details of the sketch of the model, comprehending the impact of the physical properties of the materials from the garment structure on its final shape, and he/she must also be able to visualise the $3 \mathrm{D}$ image of the model garment with what he was done before or selected.

If the designer decides to increase the length of a pattern outline contour to make the required creases, they have to be aware of the impact of this increment on the volume of the model and the necessary amount of material.

According to the results from figure 6 , for a jacket model with small creases uniformly distributed along the seamline between the main elements (front and back) and the hem band, an average value of the percentage increase of the area of the front and back components (around 25\%) determines a good level for the usage index of the base material.

Fig. 4. Modifying the position of the inferior point of the back armhole 


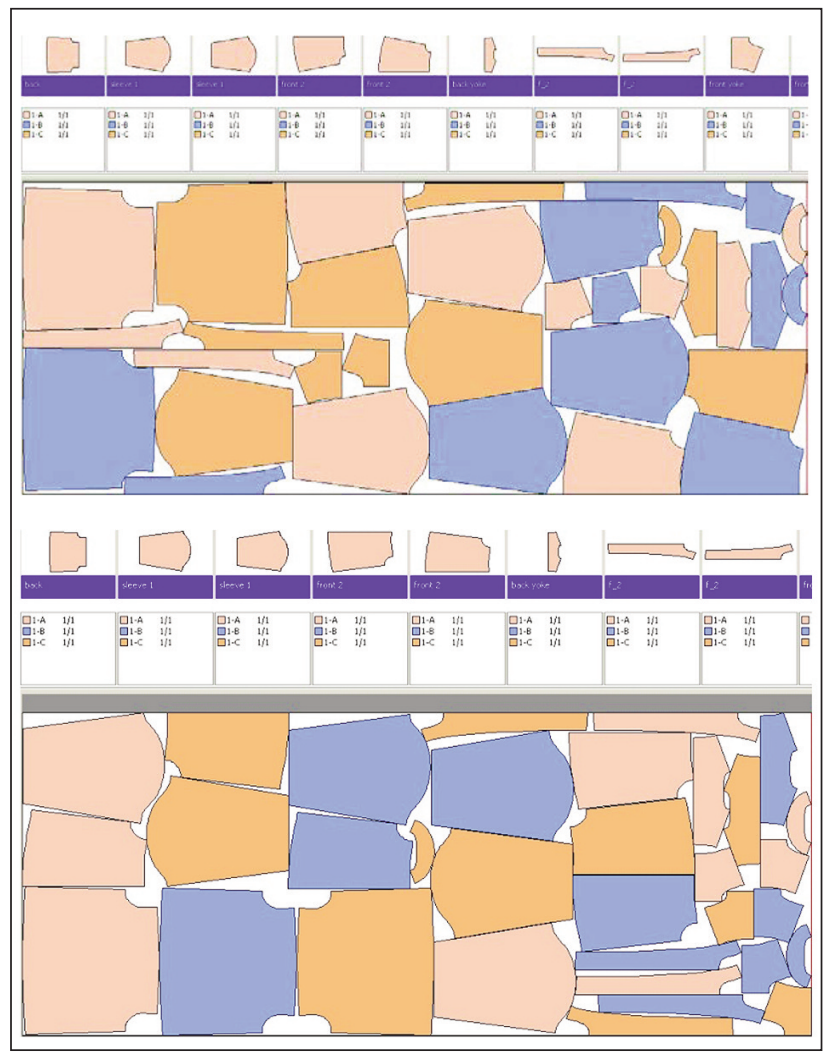

Fig. 5. Markers for the base material

This percentage corresponds to a distance of 9-12 $\mathrm{cm}$, by which the length of the contour line is increasing (along the back and front pieces). It is recommended to use appropriate values when designing the front and the back components because in this way, the lateral sideseam will have a correct position, and the volume of the model will have the desired value. The largest value of the interval $4 \mathrm{~cm}$ to $20 \mathrm{~cm}$ interval (percentage of 35-40\%), may be used if the model has numerous creases, but only for the largest size. For the smaller sizes of the model, it is recommended to use a value from [6-8] $\mathrm{cm}$ interval (percentage between 10-15\%); if one uses larger values, the shape of the model will look strange (it will

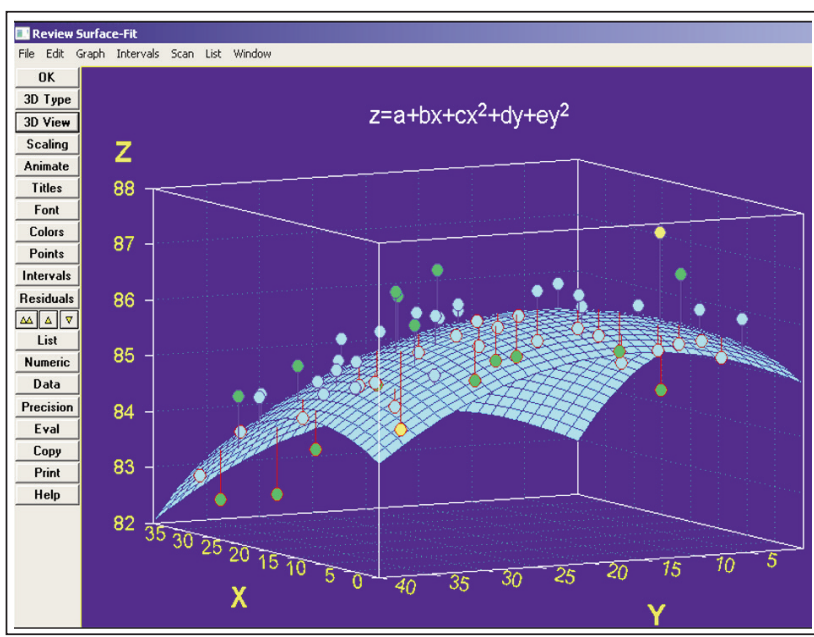

Fig. 6 . The correlation between the selected variables

have many creases along the sewing line between the front and back components with the hem band, and this will have an impact on the silhouette and the balance of the model while it is worn.

The graph shown in figure 6 illustrates the evolution of the usage index values when some components (front and back) increase or decrease. One can notice that the mathematical model is accurate, and it expresses the correlation between the selected elements. It is an initial evaluation of how the front and back surfaces' changes influence the base material usage index usage. Before manufacturing the pieces of the model, the designer will be able to get an idea regarding the garment model's technical information: volume, the necessary amount of material, and its usage index. They can use this as a starting point in developing a model with creases and won't have to look for or test other options.

\section{ACKNOWLEDGEMENTS}

The European Erasmus+ Project, named "Innovative design practices for achieving a new textile circular sector "Acronym Design4Circle, 2018-1-LV01-KA202-046977, inspired the subject of this paper.

\section{REFERENCES}

[1] Wang, Z., Xing, Y., Wang, J., Zeng, X., Yang, Y.L., Xu, S., A knowledge-supported approach for garment pattern design using fuzzy logic and artificial neural networks, In: Multimedia Tools and Applications, 2020, https://doi.org/10.1007/s11042-020-10090-6

[2] Završnik, B., Potočan, V., Clothing fashion brands, In: Industria Textila, 2020, 71, 5, 482-486, http://doi.org/ 10.35530/IT.071.05.1768

[3] Tudor, L., Change in Textile and Clothing Industry, In: Industria Textila, 2018, 69, 1, 37-43, http://doi.org/10.35530/ IT.069.01.1449

[4] Popa, A., Pelau, C., Differences in the clothing brand perception depending on generation, In: Industria Textila, 2016, 67, 4, 260-264

[5] Kim, I.H., Nam, Y.J., Han, H., A quantification of the preferred ease allowance for the men's formal jacket patterns, In: Fashion and Textiles, 2019, 6, 5, http://doi.org/10.1186/s40691-018-0165-x

[6] Avadanei, M., Filipescu, E., Ionescu, Olaru, S., The Design Process and Prototype Evaluation of Special Garments in a Virtual Environment, In: Proceedings of the 10th International Conference on Virtual Learning ICVL, 2015, 284-290 
[7] Olaru, S., Spânachi, E., Filipescu, E., Salistean, A., Virtual fitting - innovative technology for customize clothing design, In: Procedia Engineering, 2014, 69, 555-564

[8] Avadanei, M., Filipescu, E., Ionescu, I., Loghin E., E-learning demonstrations of clothes pattern alteration due to the appearance of different flaws, In: Proceedings of the 12th International Scientific Conference on eLearning and Software for Education (eLSE), 2016, 461-466, http://doi.org/10.12753/2066-026X-16-245

[9] Schwarz-Mueller, F., Marshall, R., Summerskill, S., Poredda, C., Measuring the efficacy of positioning aids for capturing $3 D$ data in different clothing configurations and postures with a high-resolution whole-body scanner, In: Measurement, 2021, 169, Article Number: 108519, http://doi.org/10.1016/j.measurement.2020.108519

[10] Gemini CAD softwear, Available at: http://www.geminicad.ro [Accessed on February 2020]

[11] Olaru, S., Filipescu, E., Filipescu, E., Niculescu, C., Salistean, A., Software solution to assess morphological body through 3D scanning results, In: Procceding of the The 9th International Scientific Conference eLearning and software for Education Bucharest, ISSN 2066-026X, 2013, 3, 391-398

[12] Brumariu, A., Filipescu, E., Dodu, A., Avadanei, M., et al., Proiectarea constructiva a produselor de îmbrăcăminte. Manualul inginerului textilist, In: Editted by Ministry of Education, Research and Youth, 2003, ISBN 973-8466-10-5, 783-1044

[13] Hong, Y., Zeng, X., Bruniaux, P., Chen, Y., Zhang, X., Development of a new knowledge-based fabric recommendation system by integrating the collaborative design process and multi-criteria decision support, In: Textile Research Journal, 2018, 88, 23, 2682-2698, http://doi.org/10.1177/0040517517729383

[14] TC32-statistical softwear

\section{Authors: \\ MANUELA AVĂDANEI, ANTONELA CURTEZA, CARMEN BLEJAN, IONUȚ DULGHERIU, EMIL CONSTANTIN LOGHIN, DORIN IONESI, CEZAR-DORU RADU}

"Gheorghe Asachi" Technical University of lasi, Faculty of Industrial Design and Business Management Prof.dr.doc. Dimitrie Mangeron Street, 28, Iasi, 700050, Romania

\section{Corresponding author:}

MANUELA AVĂDANEI

e-mail: mavad@tex.tuiasi.ro 